\title{
Developing Countries as New Growth Poles of Post-Crisis Global Economy
}

\author{
Elena Popkova', Svetlana Meshkova², Evgeniya Karpunina ${ }^{3}$, Elena Karpushko ${ }^{4}$, Marina Karpushko ${ }^{5}$
}

ABSTRACT

\begin{abstract}
This article is devoted to the search for a solution to overcoming the consequences of the global financial and economic crisis and the development of a post-crisis global economy. The purpose of this article is to determine perspectives and directions for the development of new growth poles in a post-crisis global economy and to develop tools for overcoming the consequences of the crisis and facilitating the global economic system entry into a new level of economic growth. The article uses the proprietary methodology for the calculation of "underdevelopment whirlpools," which analyzes the dynamics of economic growth of the most prominent countries in this group and their ability to overcome "underdevelopment whirlpools" and transform into new growth poles for the global economy following the global financial crisis. The use of calculation tools for "underdevelopment whirlpools" determines the prospective of developing countries'transformation into new growth poles in a post-crisis global economy. China, Japan, Brazil, Russia, and India are such poles at present, and they will strengthen their positions in the near future. For this, the research offers the following perspective and directions for the development of new growth poles in a post-crisis global economy for the increase in rates and quality (stability and sustainability) of economic growth: an emphasis on the real sector development of the economy, realization of transnational cluster initiatives, and active creation and implementation of innovations into production. As tools for overcoming the consequences of the crisis and the global economic system entering a new level of economic growth, the author developed the mechanism of post-crisis global economy development.
\end{abstract}

KEY WORDS: $\quad$ growth poles, global financial and economic crisis, post-crisis phenomena, innovations, global economy

JEL Classification: 0110

'Volgograd State Technical University, Russian Federation, ${ }^{2}$ Perm Institute of Economics and Finance, Russian Federation, ${ }^{3}$ G.R. Derzhavin Tambov State University, Russian Federation, ${ }^{4}$ Volgograd State University of Architecture and Civil Engineering, Russian Federation, ${ }^{5}$ Perm National Research Polytechnic University, Russian Federation

\section{Introduction}

Over several decades, the global economy has shown stable growth and development. However, despite positive forecasts, 2008 was marked by the global financial

\section{-}

Correspondence concerning this article should be addressed to: Elena Popkova, Volgograd State Technical University, 28 Lenina St. Volgograd 400000 Russian Federation. E-mail: elenapopkova@yahoo.com crisis, the consequences of which - unemployment, inflation, and reduction of economic growth - influenced even the most economically developed countries.

At present, the global economic system is in postcrisis conditions. To overcome the current recession, it is necessary to reconsider traditional approaches to the provision of economic growth and search for new sources of growth. In this context, it is necessary to focus on the gradual restructuring trends of the global economy. 
Developed countries, which occupy leading positions in the global economy, have almost depleted their potential for further development and realization of strategies to preserve these positions. Indeed, they are overcome in this aspect by developing countries, which possess significant potential for development. Most importantly, the motivation to search for new solutions and actualize new ideas, i.e., the creation and implementation of innovations, is led by developing countries.

Innovations have been a moving force of the global economy, not only over the past few decades but throughout the entire history of mankind. Research has shown that the implementation of innovations has allowed previous global crises to be overcome, which is why it is believed that the consequences of the recent financial and economic crisis will be overcome with the help of innovations.

Therefore, it is necessary to focus on sources of innovations, determine the best direction for their use, and create favorable conditions for their implementation into production. It is very likely that country-incubators of innovations will become new growth poles of the global economy in the short term.

Before the crisis, the USA and the EU were the growth poles of the global economy - they have demonstrated the highest rates of economic growth over the past 35 years and have made the greatest contribution to the formation of the global GDP. China, Japan, Brazil, Russia, and India can potentially take their place after the crisis because the total GDP of these countries exceeds the U.S. GDP, and the economy of these countries is based on the real sector of production, which shows the highest stability and sustainability levels as well as innovation potential.

This research offers a hypothesis in which the conditions of the global economic system functioning were changed cardinally due to the global financial and economic crisis, and the previous growth poles of the global economy are not capable of providing the desired effect, which necessitates the search for new growth poles and the development of working mechanisms in the post-crisis global economy to overcome the long recession.

The purpose of the article is to verify the proposed hypothesis, determine directions for development and new growth poles for the post-crisis global economy, and develop tools to overcome the consequences of the crisis and the global economic system's entry into a new level of economic growth.

\section{Literature Review}

The theoretical basis of the research is composed of fundamental works in the study of the sense, notion, and meaning of economic growth for socio-economic systems by authors such as (Pogosov, 2015; Odhiambo, 2015; Zeira \& Zoabi, 2015), among others. Economic growth is a process involving the increase in the production capabilities of an economy (Leonida et al., 2015) and can be expressed quantitatively, measured by the increase in GDP growth rates (Sarracino \& Bartolini, 2015), and qualitatively, changing the structure of the economy (González-Pernía \& Peña-Legazkue 2015). The development of modern economic systems is impossible without economic growth (Choi \& Shin, 2015; Lee \& Oh, 2015). Therefore, economic growth influences the development of any socio-economic system (Castiglione, Infante, \& Smirnova, 2015).

This article also uses material from recent studies that analyze the peculiarities, factors, and conditions of global economic development at present and the growth poles of various economic systems, among which studies by (Bere, 2015; Kolomiets, 2015; Smékalová, Hrabinová, \& Habuda, 2014), among others, can be distinguished. The most important peculiarity of modern global economic development is its orientation toward building and developing market relations (Dymskill, 2013) and establishing priorities for the development of the service sphere, which is one of the most important growth poles of the modern global economic system (Ravuri, 2012). The most important factors of global economic development are the globalization and integration of various economic systems (Christofakis \& Papadaskalopoulos, 2011), as well as the creation and implementation of innovations for the production activities of business structures (Fuseini \& Kemp, 2015).

While conducting research, the author found studies on the foundations of the functioning of the modern global economy and the trends of its development in the past and prospective views, including studies by (Docquier \& Machado, 2015; Ilie \& Jaradat, 2015; Yakovleva, Azarova, \& Titova, 2015), among others. The modern global economic system is based on the 

Table 1. Table for determining the depth and speed of countries falling into "underdevelopment whirlpools" and perspectives for overcoming these whirlpools

\begin{tabular}{|c|c|c|c|c|c|}
\hline Country & Year & V & $\mathrm{Y}$ & Dwhirlpool & Swhirlpool \\
\hline 1 & $1,2, \ldots, \mathrm{n}$ & $\vee 1,2, \ldots, n$ & $Y 1,2, \ldots, n$ & Year-Y & $\begin{array}{l}\text { Dwhirlpool2- } \\
\text { Dwhirlpool1 }\end{array}$ \\
\hline 2 & $1,2, \ldots, \mathrm{n}$ & $\mathrm{V} 1,2, \ldots, \mathrm{n}$ & $Y 1,2, \ldots, n$ & Year -Y & $\begin{array}{l}\text { Dwhirlpool2- } \\
\text { Dwhirlpool1 }\end{array}$ \\
\hline$\cdots$ & $\ldots$ & $\ldots$ & $\cdots$ & $\cdots$ & $\cdots$ \\
\hline$n$ & $1,2, \ldots, \mathrm{n}$ & $\mathrm{V} 1,2, \ldots, \mathrm{n}$ & $Y 1,2, \ldots, n$ & Year -Y & $\begin{array}{l}\text { Dwhirlpool2- } \\
\text { Dwhirlpool1 }\end{array}$ \\
\hline
\end{tabular}

year to the level of the GDP of the "model country" in one of the previous years is determined.

As a result, the difference between the selected year and the year in which the GDP level of the "model country" coincided with the GDP level in the studied country is determined. The resulting difference reflects the depth of the "underdevelopment whirlpool." The speed of being drawn into the "underdevelopment whirlpool" is determined as the difference between the depths of the "underdevelopment whirlpool" in the current year and the previous year.

Table 1 uses the following legend:

$\mathrm{V}$ - GDP per capita;

$\mathrm{Y}$ - year in which the country model had the same GDP per capita;

Dwhirlpool - depth of the "underdevelopment whirlpool";

Swhirlpool - speed of being drawn into the "underdevelopment whirlpool."

With regard to the analysis of the growth poles of the post-crisis global economy, this methodology is expected to determine the dynamics of economic growth of top leading countries and trends regarding their overcoming "underdevelopment whirlpools," taking leading positions instead of the ones lagging behind in contributing to the formation of the global GDP and their transformation into new growth poles of the global economy following the global financial crisis.

\section{Results}

Before the 2008 global financial crisis, the growth poles of the global economy were the U.S. and countries in the EU, which have demonstrated the highest rates of economic growth and contributed the most to the formation of the global GDP over the last 35 years.

The crisis in the global economy deepened the gap between developed and developing countries in the global economic system, which led to larger migration flows into EU countries. This may be a reason for some countries to leave the EU and further weaken its positions.

It is also possible to suppose that the financial sphere, which has been a growth pole for the U.S. economy in recent decades, depleted its possibilities. Financial speculations were the main cause for the recent financial crisis, which demonstrated their high risk component and incapacity for the provision of stable economic growth.

In this context, the economic growth of industrial countries by means of industrial production and development of the real sector of the economy attracts a significant amount of attention. Such countries include China, Japan, Brazil, Russia, and India, which occupy leading positions in the global GDP rankings of countries and increasingly contribute to the formation of gross global product.

Several decades ago, these countries did not attract any attention in view of economic development and were far from leading positions in international rankings. However, they have made major advances and continue to develop. Figure 1 shows the dynamics of GDP of the USA, Japan, Russia, Brazil, and India over the past 35 years.

With the help of the calculation methodology for "underdevelopment whirlpools," let us view the process of development of these countries (Tables 2, 3). 


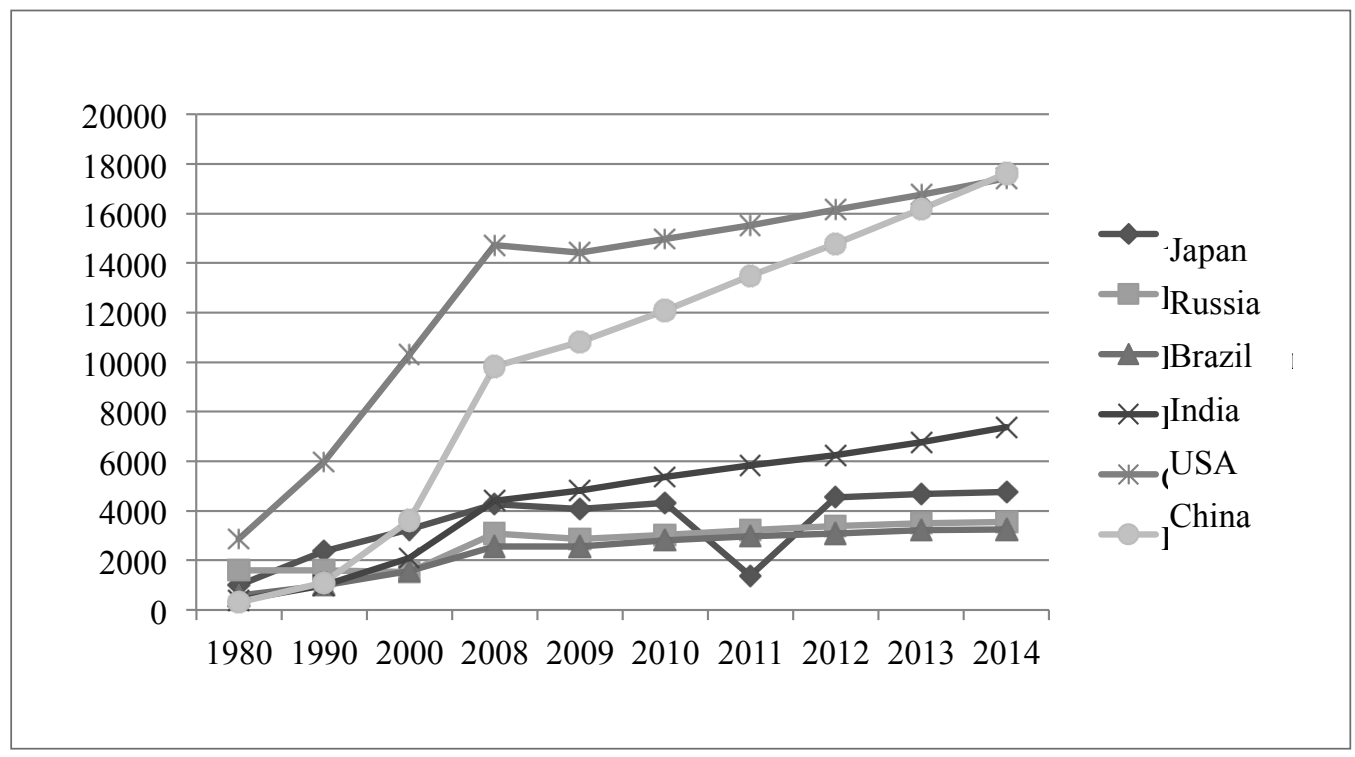

Figure 1. GDP dynamics of the USA, Japan, Russia, Brazil, and India from 1980 to 2014.

Source: IMF (2015)

Table 2. Results of the calculation of "underdevelopment whirlpools" in China and determination of perspectives of its transformation into a new growth pole of the post-crisis global economy

\begin{tabular}{lccccc}
\hline Country & Year & V, USD billion & Y & Dwhirlpool & Swhirlpool \\
\hline 1980 & 298.4 & 1970 & 10 & - \\
& 1990 & $1,091.2$ & 1975 & 15 & 2 \\
& 2000 & $3,608.3$ & 1983 & 17 & -8 \\
& 2008 & $9,826.8$ & 1999 & 9 & -1 \\
& 2009 & $10,813.8$ & 2001 & 6 & -2 \\
China & $12,085.5$ & 2004 & 6 & 0 \\
& 2010 & $13,482.1$ & 2005 & 4 & -2 \\
& 2011 & $14,789.5$ & 2008 & 1 & -3 \\
\hline
\end{tabular}

The model country is the USA, which has been a key growth pole in the global economy in recent decades. China has the highest indicators of GDP among the countries in the world, so it is advisable to view it separately.
Japan, Brazil, Russia, and India also demonstrated high rates of economic growth in recent decades. However, they cannot separately compete with current global leaders, so it is advisable to group them and view their total contribution to the formation of the global GDP. 
Table 3. Results of the calculation of "underdevelopment whirlpools" in Japan, Brazil, Russia, and India and the determination of perspectives of their transformation into a new growth pole of the post-crisis global economy

\begin{tabular}{lccccc}
\hline Countries & Year & V, USD billion & Y & Dwhirlpool & Swhirlpool \\
\hline & 1980 & $3,549.0$ & 1982 & -2 & - \\
& 1990 & $5,955.1$ & 1990 & 0 & 2 \\
& 2000 & $8,453.2$ & 1996 & 4 & 4 \\
Japan, Brazil, Russia, & 2008 & $14,329.9$ & 2007 & 1 & -3 \\
India, SAR & 2009 & $14,328.0$ & 2007 & 2 & 1 \\
& 2010 & $15,522.5$ & 2011 & -1 & -3 \\
& 2011 & $13,432.1$ & 2005 & 6 & 7 \\
& 2012 & $17,272.7$ & 2014 & -2 & -8 \\
& 2013 & $18,172.9$ & 2015 & -2 & 0 \\
& 2014 & $18,955.0$ & 2016 & -2 & 0 \\
\hline
\end{tabular}

As observed from Table 2, at the beginning of the viewed period in 1980, China lagged behind the USA by 10 years in terms of economic development. In 1990, the depth of the "underdevelopment whirlpool" grew by 15 years, and in 2000, by 17 years. However, given the crisis conditions, in 2008, the gap between the GDP levels of China and the USA was reduced to 9 years.

Afterward, under the conditions of the post-crisis global economy, a negative speed of being drawn into the "underdevelopment whirlpool" is observed, and this pressure of the underdevelopment whirlpool is overcome. In 2014, the Chinese GDP exceeded the GDP of the USA ( $\$ 17,617.30$ billion versus $\$ 17,418.90$ billion).

As observed from Table 3, the total GDP of Japan, Brazil, Russia, and India at the beginning of the viewed period in 1980 exceeded the American GDP. However, in 2000, an "underdevelopment whirlpool" appeared, the depth of which constituted 4 years. Beginning in 2014, the total GDP of these countries exceeds the GDP of the USA.

The use of calculation tools for "underdevelopment whirlpools" allowed for the determination of turning the countries that lagged behind into new growth poles of the post-crisis global economy. China, Japan, Brazil, Russia, and India are such poles now, and according to the IMF forecast, will strengthen their positions in this role in the near future.

To this end, the research offers the following prospective directions for the development of new growth poles of the post-crisis global economy to increase the rates and quality (stability and sustainability) of economic growth:

- emphasis on the development of the real sector of the economy, which is necessary for the provision of sustainable development;

- the realization of transnational cluster initiatives, which is oriented toward the increase in economic growth rates;

- the active creation and implementation of innovations into production, which is important for positive economic development.

Let us view the above proposals in detail. An emphasis on the development of the real sector of the economy supposes an industrial direction of new growth poles in the post-crisis global economy. This does not mean that the development of the sphere of services and agriculture should not be given any attention - the importance of these spheres is not diminished but rather moves into the background, making way for the production sphere. 
Goal:

overcoming the consequences of the global financial crisis, overcoming the recession, and transition to a new level of economic growth

Tasks (directions of development):

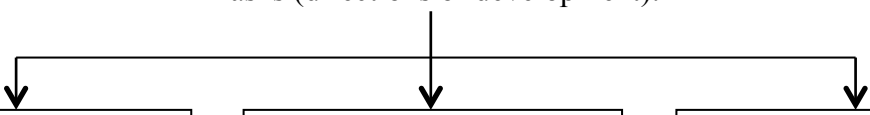

emphasis on the development of a real sector of the economy

realization of transnational cluster initiatives active creation and implementation of innovations into

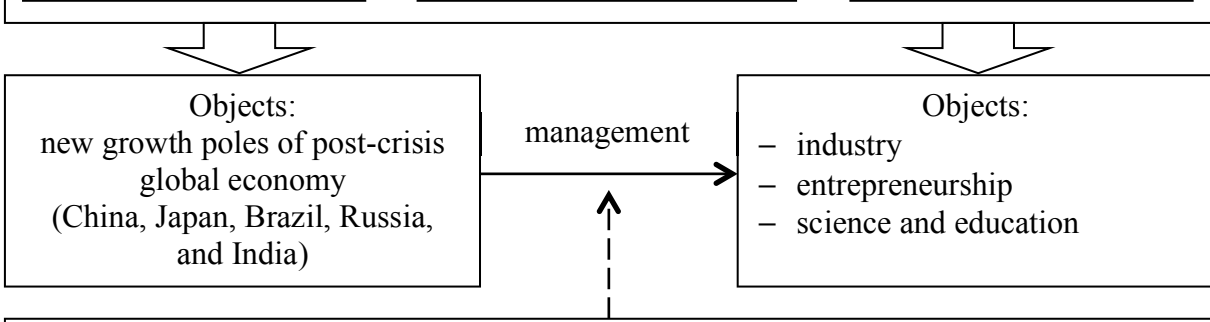

Tools:

concessional lending and financing of universities, industrial clusters, realization of modernization programs, improvement of legislature in the sphere of clustering and patenting of innovations, stimulation of business activities in industrial production.

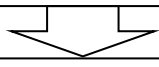

Result:

- shift of accents in economic development from the service sphere as a whole and the financial sector in particular to the sphere of industrial production;

- the reduction of the risk component of economic development;

- setting innovations as the basis of economic growth;

- increase in rates of economic growth;

- increase in stability and sustainability of economic growth.

Figure 2. Mechanism of development of the post-crisis global economy

The realization of transnational cluster initiatives is oriented toward the determination of strong transnational connections and the further integration of growth poles into the global economic system. To withstand international competition, companies from these countries have to combine efforts and cooperate within transnational clusters.
The active creation and implementation of innovations into production supposes the development of research and education. The development of science will lead to the creation of multiple inventions and innovational technologies. Information on new knowledge should be distributed throughout the entire economy to successfully commercialize 
innovations and ensure their quick implementation into production.

An increase in the educational level will stipulate the creation of highly qualified human resources that are capable of using the newest technologies and equipment, which will create favorable conditions for the modernization of the production sector and the formation of industrial enterprises, which are highly competitive in the global markets.

As tools for the realization of the current potential of the global economic system for overcoming the consequences of the global financial crisis, overcoming the recession, and transitioning to a new level of economic growth, this research offers the following mechanism of development for the post-crisis global economy (Fig. 1).

As observed from Fig. 1, the proposed mechanism is oriented at overcoming the consequences of the crisis and the global economic system's transition to a new level of economic growth. The objective of the mechanism is to develop new growth poles of the post-crisis global economy (China, Japan, Brazil, Russia, and India).

The objective of the mechanism in terms of developing the real sector of the economy is developing industries. In terms of the realization of transnational cluster initiatives, the objective is entrepreneurship, and for the active creation and implementation of innovations into production, the objective is increased research and education.

To achieve the set goal for the realization of the prospective directions of the development of new growth poles in the post-crisis global economy, a special tool is used. For the development of the production sector of the economy, it is advisable to use the following tools to stimulate the state:

- the provision of subsidized credits for the modernization of equipment;

- the stimulation of business activities in industrial production.

For realization of cluster initiatives, the following tools should be used:

- the provision of financial resources to clusters under concessional terms;

- the improvement of laws in the clustering sphere. For development of research and education, the following tools should be used:

- improvement of the system for patenting innovational technologies;
- increased financing of universities, scientific research and developments, and the active provision of budgets in universities to popularize higher education and increase its accessibility.

The expected and most probable results of the realization of the mechanism are the shift in emphasis in economic development from the service sphere on the whole and the financial sector in particular to the sphere of industrial production, the reduction of risk components in economic development, the establishment of innovations into the basis of economic growth, the increase in rates of economic growth, and the increase in stability and sustainability of economic growth.

\section{Conclusion}

Thus, due to the use of the analysis methodology of "underdevelopment whirlpools" and the study of the development dynamics of the most promising countries, the proposed hypothesis is proven in which it is determined that the new growth poles of the postcrisis global economy are China, Japan, Russia, Brazil, and India.

The shift of the emphasis in the global economic system confirms the expediency of the use of new development mechanisms for overcoming the consequences of the crisis and the provision of the new quality of growth in the global economy, which include the mechanism developed by the authors of this study.

As a result of this research, it is possible to conclude that, like any system, the global economy can change its structure; however, this requires new approaches to its analysis. Despite the wide diversity of the corresponding methods, this type of analysis is difficult to model and forecast.

The developed tools allow countries to overcome the consequences of the global financial crisis and use the crisis as stimulation for development, without which there are no stimuli for new knowledge, and the implementation of innovations does not proceed.

The crisis also demonstrated the mistakes of state management and the non-effectiveness of previous methods of stimulation for economic growth and development. A new vector of growth in the global economy should be an industry that develops in a stable manner, and the poles of growth should be countries with industrial foci. 
Despite the practical direction, the results of this study are limited by the theoretical consideration of the problem of overcoming the post-crisis phenomena in the global economy, determination of new poles of growth, and development of tools for maximal use of poles to transition the global economic system to a new level of economic development.

In conducting further research on the global economy's departure from a post-crisis state, researchers should focus on checking the results of this research with experiments and comparing the expectations for the establishment of China, Japan, Brazil, Russia, and India as new growth poles of the global economy. The practical use of the developed tools should be emphasized.

Further development of the theory and methodology of the "underdevelopment whirlpools" should base its validity on the example of countries that have not yet been the objects of the research of "underdevelopment whirlpools" to determine its universality and effectiveness.

This research was conducted with financial support of the Russian Humanitarian Scientific Fund, Project No. 15-22-01011: “Theoretical and methodological foundations of the marketing provision for the innovational development of intellectual resources of the Republic of Belarus and the Russian Federation under the conditions of economic integration (by the example of creation of universities of the entrepreneurial type)."

This research was conducted with financial support from the Ministry of Education and Science of the Russian Federation, Project No. 2797: "Formation of the system of scientific and production clusters in regions of Russia."

\section{References}

Aytaç, I. A., Rankin, B., \& İbikoğlu, A. (2015). The social impact of the 2008 global economic crisis on neighborhoods, households, and individuals in Turkey. Social Indicators Research, 124(1), 1-19.

Bere, R. C. (2015). Institutional structures in the growth pole policy from Romania. Administratie si Management Public, 2015(24), 64-86.

Capello, R., Caragliu, A., \& Fratesi, U. (2015). Global trends and the economic crisis: Future alternative European growth strategies. Technological Forecasting and Social Change, 98, 120-136.
Castiglione, C., Infante, D., \& Smirnova, J. (2015). Environment and economic growth: is the rule of law the go-between? The case of high-income countries. Energy, Sustainability and Society, 5(26), (n.d.) DOI: 10.1186/s13705-015-0054-8.

Čaušević, F. (2015). Globalization, Southeastern Europe, and the world economy. Abington, UK: Routlege.

Choi, K. H., \& Shin, S. (2015). Population aging, economic growth, and the social transmission of human capital: An analysis with an overlapping generations model. Economic Modelling, 50, 138-147.

Christofakis, M., \& Papadaskalopoulos, A. (2011). The growth poles strategy in regional planning: The recent experience of Greece. Theoretical and Empirical Researches in Urban Management, 6(2), 5-20.

Docquier, F., \& Machado, J. (2015). Global competition for attracting talents and the world economy. World Economy, 39(4), 530-542.

Dudin, M. N., \& Frolova, E. E. (2015). The balanced scorecard as a basis for strategic company management in the context of the world economy transformation. Asian Social Science, 11(3), 282-288.

Dymskill, G. (2013). The problem of power in finance in India and Brazil: From targets of opportunity to poles of self-reinforcing growth? In B. Dasgupta (ed.), Non-mainstream dimensions of global political economy: Essays in honour of Sunanda Sen, (pp. 45-67). Abington, UK: Routlege.

Fuseini, I., \& Kemp, J. (2015). A review of spatial planning in Ghana's socio-economic development trajectory: A sustainable development perspective. Land Use Policy, 47, 309-320.

Galbraith, J. K. (2012). Inequality and instability: A study of the world economy just before the great crisis. Inequality and Instability: A Study of the World Economy Just Before the Great Crisis. Oxford, UK: Oxford University Press.

González-Pernía, J. L., \& Peña-Legazkue, I. (2015). Export-oriented entrepreneurship and regional economic growth. Small Business Economics, 45(3), 505-522.

Guttmann, R. (2015). Chronic macro-economic and financial imbalances in the world economy: A meta-economic view. Revista de Economia Politica, 35(2), 203-226. 
Heinrich, T., Kobayashi, Y., Bryant, K. A. (2016). Public opinion and foreign aid cuts in economic crises. World Development, 77, 66-79.

Hieronymi, O. (2016). The crisis of international finance, the Eurozone and economic growth. In S. P. S. Rossi, \& R. Malavi (Eds.), Financial crisis, bank behaviour and credit crunch (pp. 3-18). Berlin: Springer.

Ilie, C., \& Jaradat, M. (2015). Co-operation in the world economy. Quality - Access to Success, 16, 168-173.

International Monetary Fund (IMF) (2015). World Economic Outlook. GDP by Country 1980-2014. Retrieved from http://knoema.ru/tbocwag/gdpby-country-1980-2014

Klinov, V. G. (2015). The evolution of long waves in the world economy. Studies on Russian Economic Development, 26(3), 285-294.

Kolomiets, G. M. (2015). Risk management as a factor of sustainable development of the world economy. Actual Problems of Economics, 165(3), 43-49.

Kornev, A. K., Maksimtsova, S. I., Treshchina, S. V. (2015). Experience in world industrial development and the reindustrialization of the domestic economy. Studies on Russian Economic Development, 26(5), 460-469.

Lee, S., Oh, D. W. (2015). Economic growth and the environment in China: Empirical evidence using prefecture level data. China Economic Review, 36, 73-85.

Leonida, L., Patti, D. M. A., Marini, A., Navarra, P. (2015). Political competition and economic growth: A test of two tales. Economics Letters, 135, 96-99.

McMaster, R. (2015). The "illusion" or "paradigm blindness" of economics: Ethical challenges to economic thought from the financial crisis. Marx, Veblen, and the Foundations of Heterodox

Odhiambo, N. M. (2015). Government expenditure and economic growth in South Africa: An empirical investigation. Atlantic Economic Journal, 43(3), 393-406.

Pogosov, I. A. (2015). Factors of long-term economic growth: Scientific and technical progress and capital intensity of production. Studies on Russian Economic Development, 26(5), 423-433.

Popkova, E. G., Akopova, E. S., Budanova, I. M., \& Natsubidze, A. S. (2013a). The directions of transition of economic systems to new quality of economic growth. World Applied Sciences Journal, 26(9), 1180-1184
Popkova, E. G, Zubakova, N. N., Bogdanov, D. V., Yakovleva, E. A, \& Nebesnaya, A.Y. (2013b). Measurement of economic growth as a factor of development of strategies of economic transformation. World Applied Sciences Journal, 25(2), 264-269.

Popkova, E. G., \& Tinyakova, V. I. (2013a). New quality of economic growth at the present stage of development of the world economy. World Applied Sciences Journal, 24(5), 617-622.

Popkova, E. G., \& Tinyakova, V. I. (2013b). Dialectical methodology of analysis of economic growth. World Applied Sciences Journal, 24(4), 467-475.

Popkova, E. G., \& Tinyakova, V. I. (2013c). Drivers and contradictions of formation of new quality of economic growth. Middle East Journal of Scientific Research, 15(11), 1635-1640.

Popkova, E. G., Yurev, V., Stepicheva, O., \& Denisov, N. (2015). Transformation and concentration of intellectual capital as a factor of economic growth in the modern economy. Regional and Sectoral Economic Studies, 15(1), 53-60.

Pulselli, F. M., Coscieme, L., Neri, L., Regoli, A., Sutton, P. C., Lemmi, A., \& Bastianoni, S. (2015). The world economy in a cube: A more rational structural representation of sustainability. Global Environmental Change, 35, 41-51.

Ravuri, E. D. (2012). Assessing the growth pole phenomenon in Venezuela: The case of Ciudad Guayana. In M. J. Williams, J. J. Anderson (eds.), Urban Development: Strategies, Management and Impact (pp. 77-89). New York, NY: Published by Nova Science Publishers Inc.

Rodriguez, A., Turmo, J., \& Vara, O. (2014). Financial crisis and the failure of economic theory. Abington, UK: Routlege.

Sarracino, F., \& Bartolini, S. (2015). The dark side of Chinese growth: Declining social capital and wellbeing in times of economic boom. World Development, 74, 333-351.

Smékalová, L., Hrabinová, S., \& Habuda, M. (2014). Spatial distribution of competitiveness support in the Slovakia in relation to growth poles and small and medium enterprises. Scientific Papers of the University of Pardubice, Series D, Faculty of Economics and Administration, 21(30), 95-106. 
Wirtz, J., Tuzovic, S., \& Ehret, M. (2015). Global business services: Increasing specialization and integration of the world economy as drivers of economic growth. Journal of Service Management, 26(4), 565-587.

Yakovleva, E. A., Azarova, N. A., \& Titova, E. V. (2015). Innovation as a vector of regional economic development and a necessary condition for the progress of the world economy. Asian Social Science, 11(20), 90-96.

Zeira, J., \& Zoabi, H. (2015). Economic growth and sector dynamics. European Economic Review, 79, 1-15.

Zhao, X., Jiang, X., \& Li, Z. (2015). The impact of the economic crisis on the financial performance of multinational corporations. International Review of Economics and Finance, 37, 55-68. 
